\title{
Liquid-Crystalline Thiol- and Disulfide-Based Dendrimers for the Functionalization of Gold Nanoparticles
}

\author{
Preliminary Communication
}

by Stéphane Frein ${ }^{\mathrm{a}}$ ), Julien Boudon ${ }^{\mathrm{b}}$ ), Mireille Vonlanthen ${ }^{\mathrm{a}}$ ), Toralf Scharf ${ }^{\mathrm{c}}$ ), Joaquín Barberád ${ }^{\mathrm{d}}$ ), Georg Süss-Fink ${ }^{a}$ ), Thomas Bürgi*b), and Robert Deschenaux*a)

a) Institut de Chimie, Université de Neuchâtel, Avenue de Bellevaux 51, Case postale 158, CH-2009 Neuchâtel (e-mail: robert.deschenaux@unine.ch)

b) Institut de Physique, Université de Neuchâtel, Avenue de Bellevaux 51, CH-2000 Neuchâtel (e-mail: thomas.buergi@unine.ch)

c) Institut de Microtechnique, Université de Neuchâtel, Rue A.-L. Breguet 2, CH-2000 Neuchâtel

d) Química Orgánica, Facultad de Ciencias-Instituto de Ciencia de Materiales de Aragón, Universidad de Zaragoza-CSIC, E-50009 Zaragoza

Liquid-crystalline dendrons carrying either a thiol or disulfide function which display nematic, smectic A, columnar, or chiral nematic phases have been synthesized. Their mesomorphic properties are in agreement with the nature of the mesogenic units and structure of the dendrons. The first-generation poly(aryl ester) dendron containing two cyanobiphenyl mesogenic units was used to functionalize gold nanoparticles. For full coverage, a smectic-like supramolecular organization on the nanometer scale is observed, when the gold nanoparticles are spread onto carbon-coated copper grids. This result indicates that the dendritic ligands reported here act as self-organization promoters.

Introduction. - Rational design of novel supramolecular materials for applications in optics, electronics, catalysis, and biomedical sciences is still a challenge [1], current interest with this aim being focused on the synthesis of thermotropic liquid-crystalline gold nanoparticles [2-5]. Decorated gold nanoparticles are one of the most promising candidates for self-organization leading to bulk metamaterials, i.e., materials with nonconventional electromagnetic properties. It has already been shown that regular arrangements of metallic particles on different length scales can lead to negative magnetic permeability [6]. This opens the pathway to metamaterials in the visible light region, provided that the following conditions are fulfilled: the distance and organization of the particles have to be controlled, and there should be a possibility to compensate optical absorption by incorporation of active agents to allow energy transfer [7]. The first condition is fulfilled by the self-organization within the liquidcrystal phase itself, while the second one can be fulfilled by adding fluorescence dyes into the liquid-crystal materials.

To generate mesomorphism, gold nanoparticles were functionalized with liquidcrystalline thiol derivatives [2-4] via a ligand-exchange reaction from dodecane-1thiol-stabilized gold nanoparticles [8]. Only in one case, the mesophase displayed by the materials could be identified [4]: an enantiotropic nematic phase was obtained for gold nanoparticles partly decorated with laterally-branched mesogens; the latter 
ligands showed a monotropic nematic phase. Alternatively, gold nanoparticles were partly functionalized with non-mesomorphic second-generation poly(benzyl ether) dendrons [5] also via a ligand-exchange reaction to give an enantiotropic $\operatorname{Im} \overline{3} \mathrm{~m}$ cubic phase.

We designed mesomorphic materials by functionalizing [60]fullerene (nematic, chiral nematic, smectic A, smectic C, columnar phases) [9], [60]fullerene-ferrocene dyads (smectic A phase) [10], and diruthenium clusters (nematic and smectic A phases) [11] with liquid-crystalline dendrimers. The nature of the mesophases and the supramolecular organization within the liquid-crystal state could be controlled via the structure of the mesomorphic units, and the structure and size (generation) of the dendrons. Therefore, structural engineering at the molecular level led to materials with tailored-made mesomorphic properties.

Based on this experience, we envisaged to apply this concept to gold nanoparticles. Indeed, gold nanoparticles are three-dimensional molecular objects, such as [60]fullerene, ferrocene, and organometallic clusters, the self-organization behavior of which could also be generated and controlled by use of liquid-crystalline dendrons [12]. We report herein the synthesis, characterization, and liquid-crystalline properties of thioland disulfide-based dendrons, and the functionalization of gold nanoparticles with one of the ligands.

Results and Discussion. -1 . Design. This study focuses on the preparation of first(i.e., 1, 2, and 8), second- (i.e., $\mathbf{3}, \mathbf{4}, \mathbf{5}$, and 6), and third- (i.e., 7) generation dendrons containing either a thiol or disulfide group (Schemes 1-5). The disulfide function (two anchor sites) was selected to design ligands having stronger binding constants than the thiol derivatives (one anchor site). Thus, eight ligands were designed and classified within three families according to their structures: 1) poly(aryl ester) dendrons functionalized with mesomorphic cyanobiphenyl units (i.e., compounds 1-4; Schemes 1 and 2), 2) poly(benzyl ether) dendrons carrying alkyl chains (i.e., compounds 5-7; Schemes 3 and 4), and 3) a poly(aryl ester) dendron carrying optically-active mesogens (i.e., compound $\mathbf{8}$, Scheme 5).

2. Synthesis. The preparation of compounds $\mathbf{1 - 8}$ is presented in Schemes 1-5. They are obtained by esterification of first- (i.e., 9 and 13), second- (i.e., 10 and 11), or third$($ i.e., 12) generation HO-based dendrons with either 11-sulfanylundecanoic acid $(\rightarrow \mathbf{1}$, $\mathbf{3}$, and $\mathbf{5}$ ) or lipoic acid (=1,2-dithiolane-3-pentanoic acid; $\rightarrow \mathbf{2 , 4 , 6}, \mathbf{7}$, and $\mathbf{8}$ ) under standard reaction conditions. The syntheses of the precursors 9 [13], 10 [13], and $\mathbf{1 3}$ [14] had already been published, and the precursors 11 [15a] and 12 [15a] have been prepared as described in the literature.

3. Liquid-Crystalline Properties. The liquid-crystalline and thermal properties of compounds 1-8 were investigated by polarized optical microscopy (POM) and differential scanning calorimetry (DSC). The phase-transition temperatures and enthalpies are reported in Table 1.

Dendrons 1-4 gave rise to a smectic A phase in agreement with the nature of the mesomorphic cyanobiphenyl units which tend to be oriented parallel to each other, the consequence of which was the formation of layers [9][13]. For the first-generation dendrons $\mathbf{1}$ and $\mathbf{2}$, an additional nematic phase was also obtained. The secondgeneration poly(benzyl ether) dendrons $\mathbf{5}$ and $\mathbf{6}$, carrying either a $\mathrm{SH}$ or a disulfide 


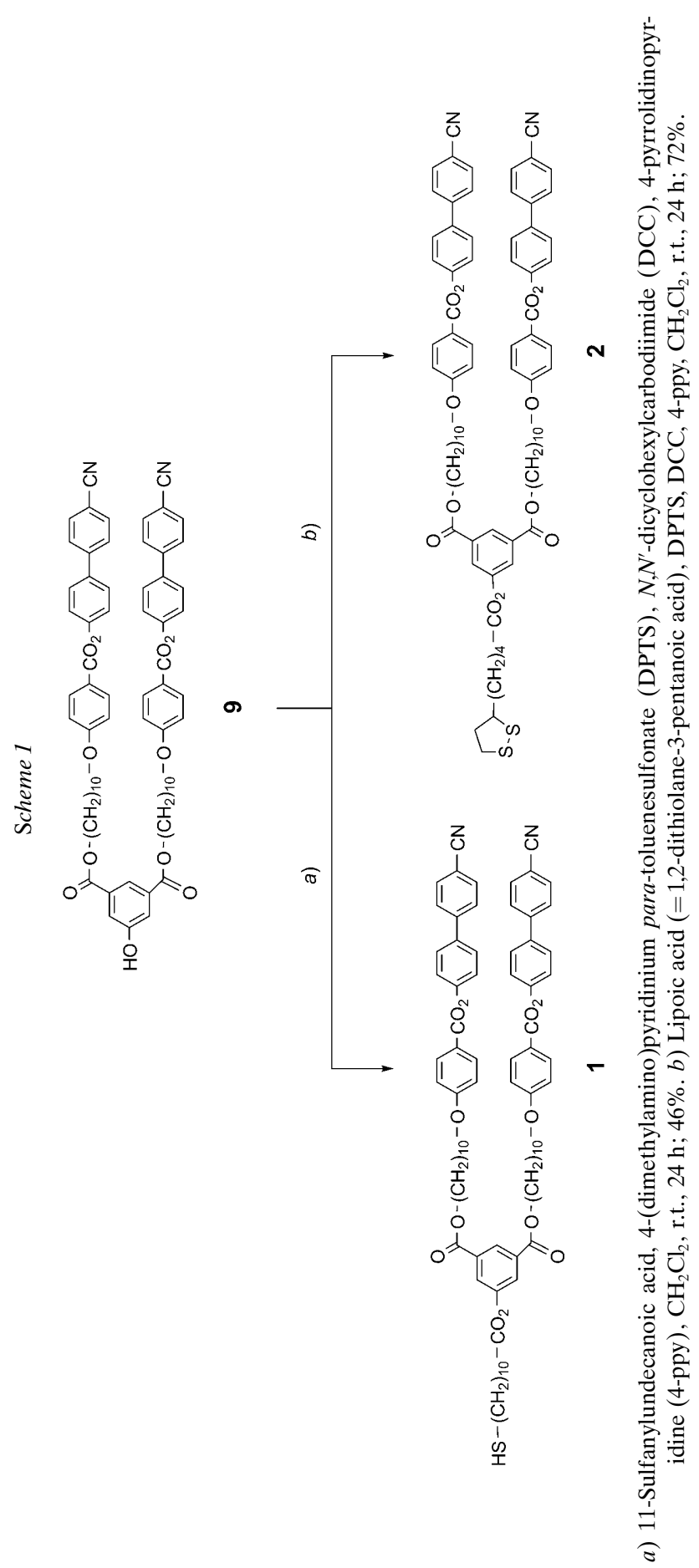




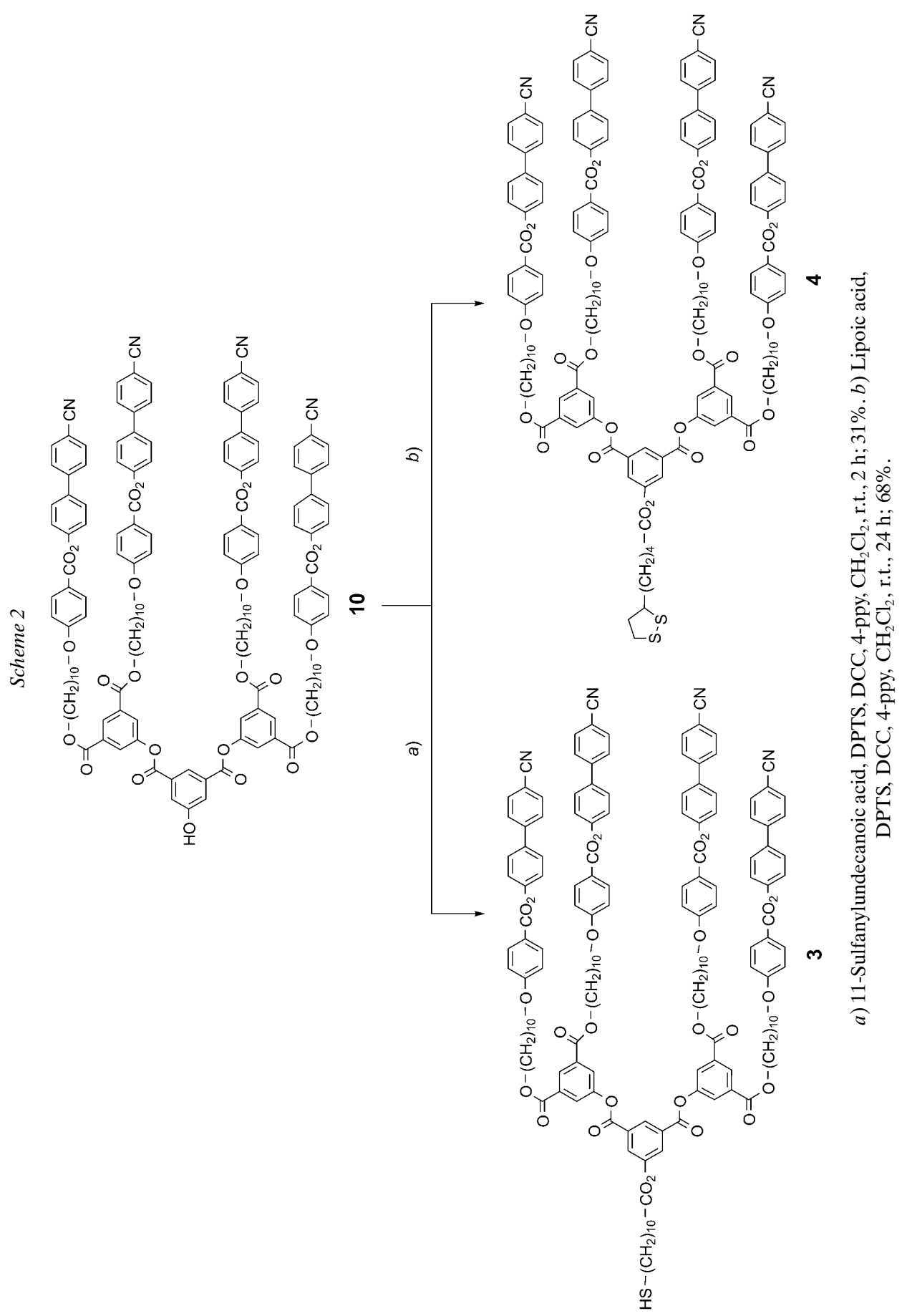


Scheme 3

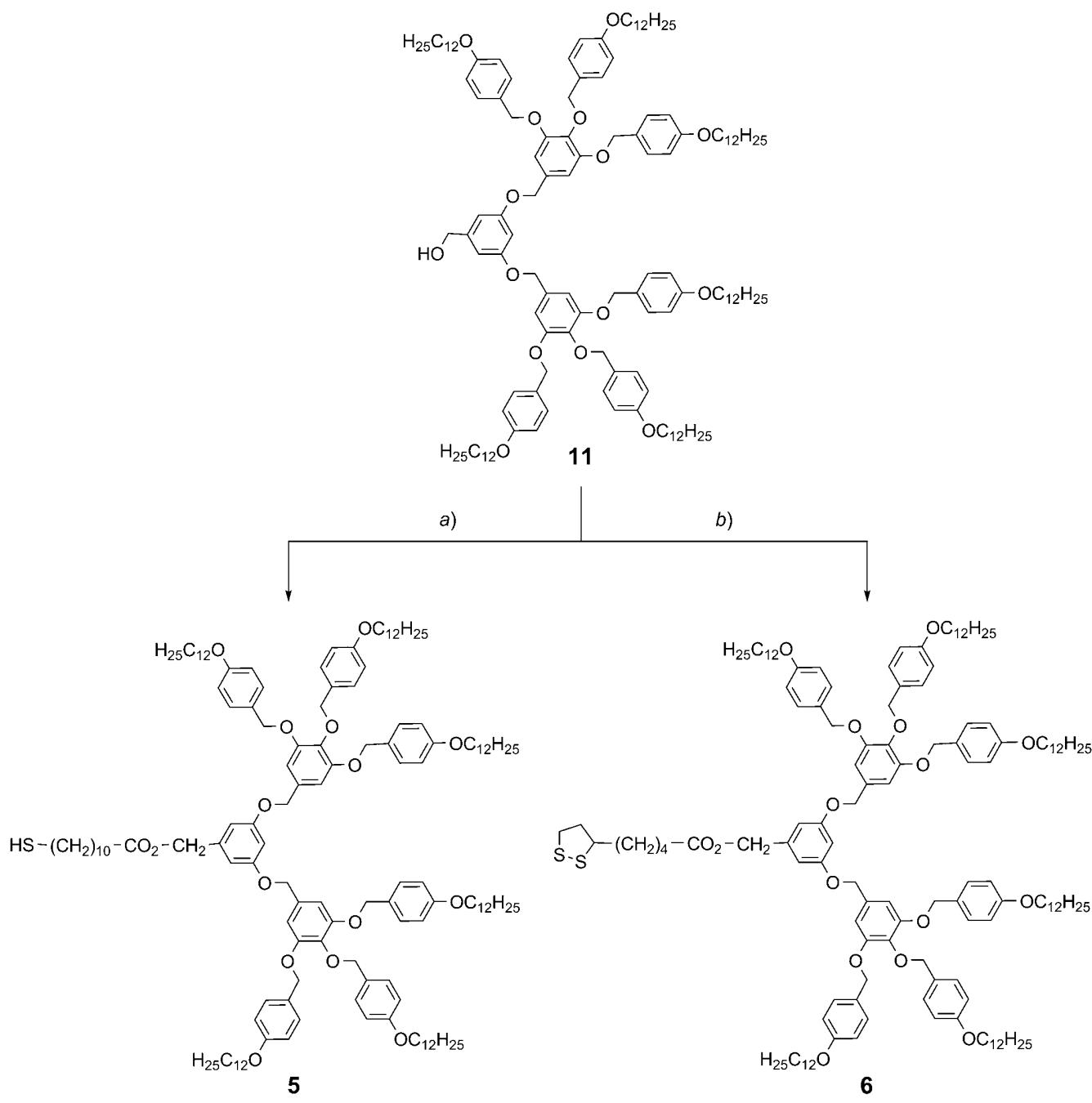

a) 11-Sulfanylundecanoic acid, DPTS, DCC, $\mathrm{CH}_{2} \mathrm{Cl}_{2}$, r.t., 24 h; 34\% . b) Lipoic acid, DPTS, DCC, 4-ppy, $\mathrm{CH}_{2} \mathrm{Cl}_{2}$, r.t., $24 \mathrm{~h} ; 67 \%$.

group, did not show mesomorphic properties, suggesting that these groups associated to the flexible alkyl chain cannot be oriented correctly in the center of the columns for mesomorphism to occur, most likely, because the size of the dendron was not large enough to surround the flexible chain in such a way that discs were formed. This was confirmed by the fact that third-generation dendron $\mathbf{7}$, which also carries a disulfide group, displayed columnar mesomorphism. The columnar phase displayed by 7 was characterized by XRD. The patterns contain a set of three sharp maxima in the smallangle region and a broad, diffuse halo in the wide-angle region (Table 2). The small- 
Scheme 4

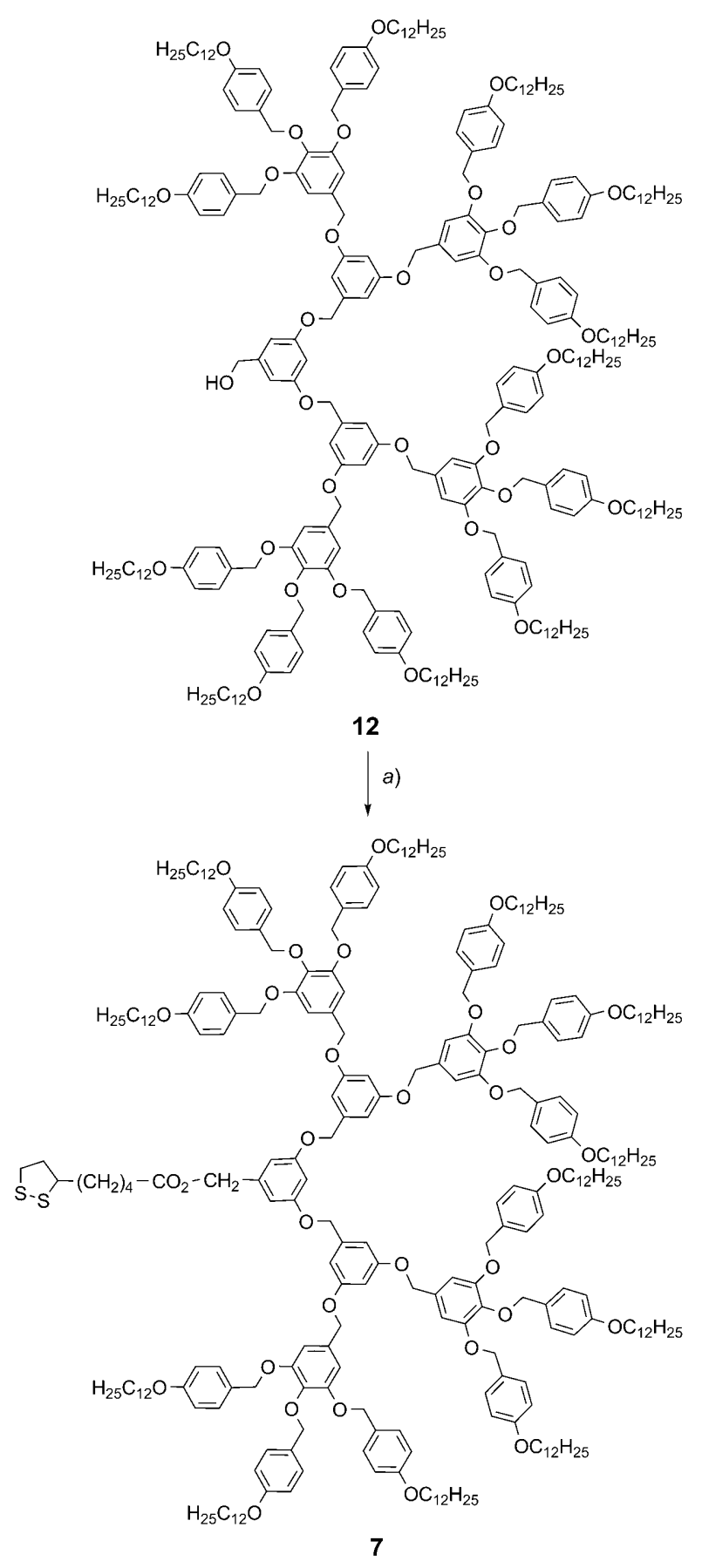

a) Lipoic acid, DPTS, DCC, $\mathrm{CH}_{2} \mathrm{Cl}_{2}$, r.t., $72 \mathrm{~h} ; 79 \%$. 
Scheme 5

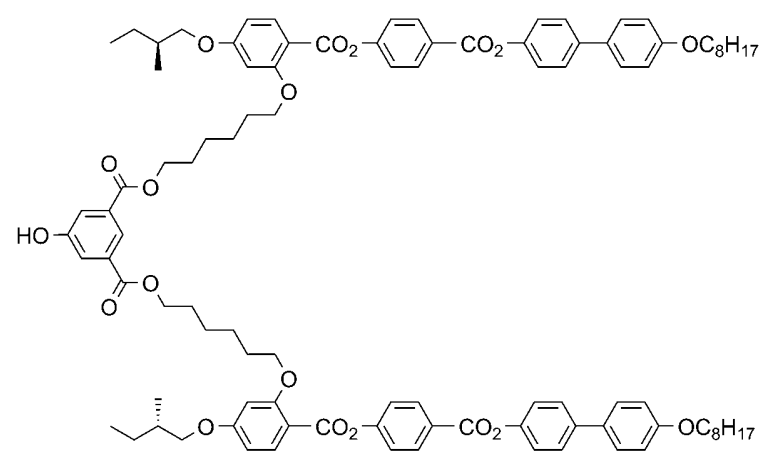

13

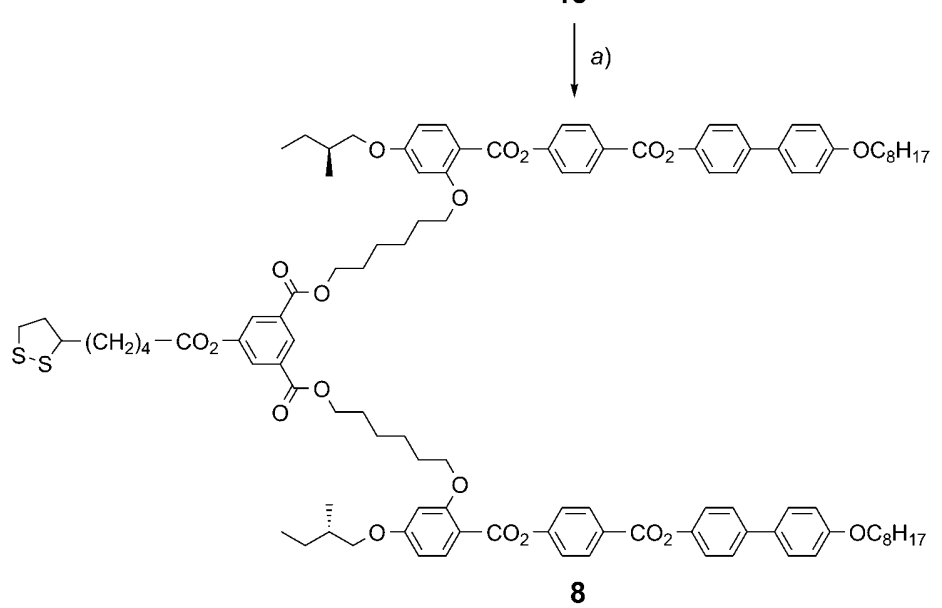

a) Lipoic acid, DPTS, DCC, 4-ppy, $\mathrm{CH}_{2} \mathrm{Cl}_{2}$, r.t., $24 \mathrm{~h} ; 71 \%$.

Table 1. Phase-Transition Temperatures $(T)$ and Enthalpy Changes $(\Delta H)$ of Compounds 1-8

\begin{tabular}{|c|c|c|c|c|}
\hline Compound & $\left.T_{\mathrm{g}}\left[{ }^{\circ}\right]^{\mathrm{a}}\right)$ & Transition $^{\mathrm{b}}$ ) & $\left.T\left[{ }^{\circ}\right]^{\mathrm{c}}\right)$ & $\Delta H[\mathrm{~kJ} / \mathrm{mol}]$ \\
\hline \multirow[t]{2}{*}{1} & 17 & $\mathrm{SmA} \rightarrow \mathrm{N}$ & 162 & 0.4 \\
\hline & & $\mathrm{N} \rightarrow \mathrm{I}$ & 175 & 1.5 \\
\hline \multirow[t]{2}{*}{2} & 22 & $\mathrm{SmA} \rightarrow \mathrm{N}$ & 161 & 0.1 \\
\hline & & $\mathrm{N} \rightarrow \mathrm{I}$ & 183 & 1.6 \\
\hline 3 & 30 & $\mathrm{SmA} \rightarrow \mathrm{I}$ & 189 & 13.6 \\
\hline 4 & 39 & $\mathrm{SmA} \rightarrow \mathrm{I}$ & 200 & 13.2 \\
\hline 5 & & $\mathrm{Cr} \rightarrow \mathrm{I}$ & 72 & 107.6 \\
\hline 6 & & $\mathrm{Cr} \rightarrow \mathrm{I}$ & 56 & 3.4 \\
\hline 7 & $\left.-^{\mathrm{d}}\right)$ & $\mathrm{Col}_{\mathrm{h}} \rightarrow \mathrm{I}$ & 104 & 8.7 \\
\hline 8 & 12 & $\mathrm{~N}^{*} \rightarrow \mathrm{I}$ & 103 & 2.0 \\
\hline
\end{tabular}

a) Glass-transition temperature. $\left.{ }^{b}\right) \mathrm{SmA}=$ smectic $\mathrm{A}$ phase, $\mathrm{N}=$ nematic phase, $\mathrm{Col}_{\mathrm{h}}=$ hexagonal columnar phase, $\mathrm{N}^{*}=$ chiral nematic phase, $\mathrm{I}=$ isotropic liquid, $\mathrm{Cr}=$ crystalline or semi-crystalline material. ${ }^{c}$ ) Transition temperatures are given at the onset of the observed peaks. ${ }^{d}$ ) Not detected. 
angle maxima correspond to a reciprocal spacing ratio of $1: \sqrt{3}: 2$, which can be indexed as the $(10),(11)$, and $(20)$ reflections of a two-dimensional hexagonal lattice. The broad halo arises from the liquid-like arrangement of the conformationallydisordered hydrocarbon chains. Its diffuse character confirmed the mesomorphic nature of this mesophase. Using density estimations, it was possible to deduce the number of molecules of compound 7 per column stratum or disc. The relationship between the density $(\rho)$ of the compound in the $\mathrm{Col}_{\mathrm{h}}$ phase and the number of molecules $(Z)$ in the unit cell is given by the following equation:

$$
\rho=(M / N) /(V / Z)
$$

where $M$ is the molar mass of the compound, $N$ the Avogadro's number, and $V$ the unit cell volume: $V=(\sqrt{3} / 2) a^{2} c \times 10^{-24}$ for a hexagonal lattice ( $a$ : hexagonal lattice constant; $c$ : stacking distance). A reflection corresponding to $c$ was not observed in the $\mathrm{X}$-ray patterns, most likely, because there is no regular stacking within the column. However, it can reasonably be assumed that the intracolumnar distance is close to $4.4 \AA$, which is the distance corresponding to the diffuse halo (Table 2). Thus, for $Z=1$, the calculated density was $0.85 \mathrm{~g} \mathrm{~cm}^{-3}$, a reasonable value for an organic compound. Therefore, considering a slice of column (or disc) with a thickness of $4.4 \AA$, it is clear that there is one molecule of compound 7 per slice or disc. The formation of columnar phases from 7 is in agreement with the nature of the dendrons [15]. Finally, the firstgeneration ligand $\mathbf{8}$, which contains optically-active laterally-branched mesogens [16], showed the formation of a chiral nematic phase.

Table 2. X-Ray Data of the Hexagonal Columnar Phase Displayed by Compound $\mathbf{7}^{\mathrm{a}}$ )

\begin{tabular}{rllll}
\hline$d_{\text {meas }}[\AA]$ & $I$ & $h k$ & $d_{\text {calc }}[\AA]$ & Phase parameters at room temperature \\
\hline 41.2 & vs & 10 & 41.2 & $a=47.6 \AA$ \\
24.1 & m & 11 & 23.8 & $S=1961 \AA^{2}$ \\
20.4 & m & 20 & 20.6 & \\
4.4 & br. & & &
\end{tabular}

a) $d_{\text {meas }}$ and $d_{\text {calc }}$ are the measured and calculated diffraction spacings, resp.; $I$ is the intensity of the reflection (vs: very strong, $\mathrm{m}$ : medium, br.: broad); $h k$ are the indexations of the reflections corresponding to the two-dimensional hexagonal lattice of the $\mathrm{Col}_{\mathrm{h}}$ phase; $a$ is the lattice parameter of the hexagonal columnar phase $\left(a=\frac{2}{\sqrt{3}} \times<d_{10}>\right.$ with $<d_{10}>=\frac{1}{N_{h k}}\left(\sum_{h, k} d_{h k} \cdot \sqrt{h^{2}+k^{2}+h k}\right)$, where $N_{h k}$ is the number of $h k$ reflections; 3 in this case); $S$ is the lattice area $\left(S=a \times<d_{10}>\right.$ for $\left.\operatorname{Col}_{\mathrm{h}}\right)$. The experiments were performed at $25^{\circ}$ both in the virgin state and after thermal treatment; the results are the same under both conditions.

The liquid-crystalline phases could be identified by POM from their characteristic textures (nematic phase: schlieren texture; smectic A phase: focal-conic fan texture and homeotropic areas; columnar phase: pseudo-focal conic texture; chiral nematic phase: plane texture; see Figs. $1-4$ for illustrative examples).

4. Functionalization of Gold Nanoparticles. The functionalization of gold nanoparticles was achieved by two alternative protocols: 1$)$ the direct synthesis [8] $(\rightarrow \mathbf{I}$; 


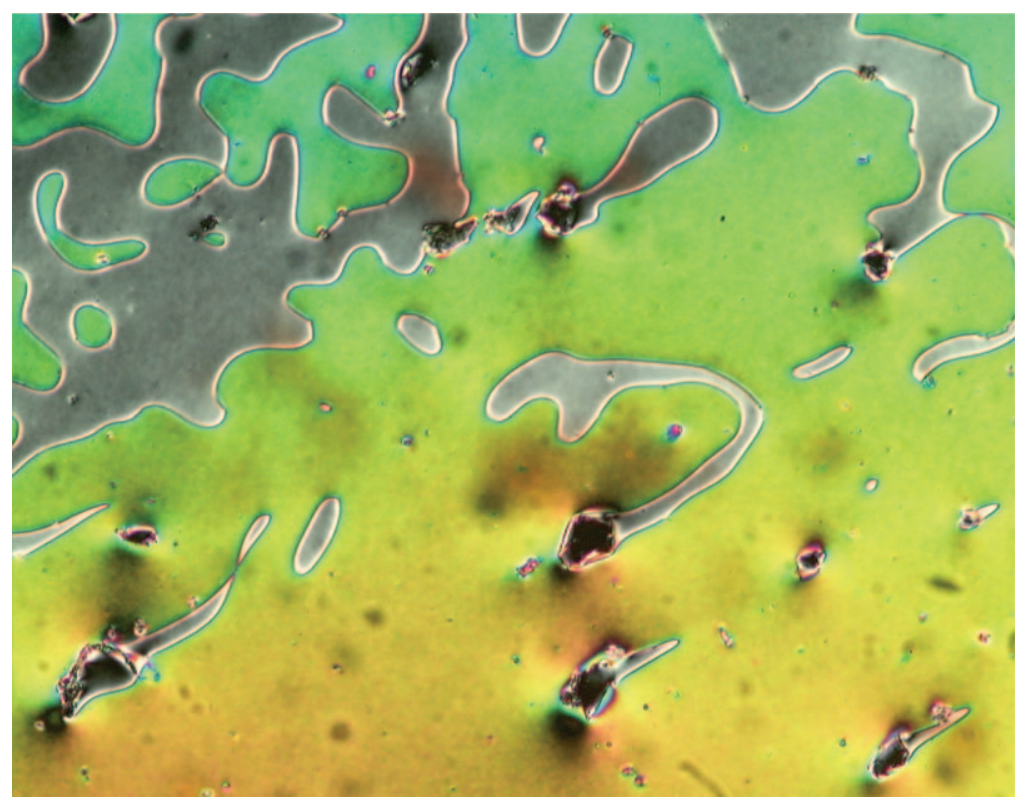

Fig. 1. Thermal-polarized optical micrograph of the texture displayed by $\mathbf{1}$ in the nematic phase upon cooling the sample from the isotropic liquid to $173^{\circ}$

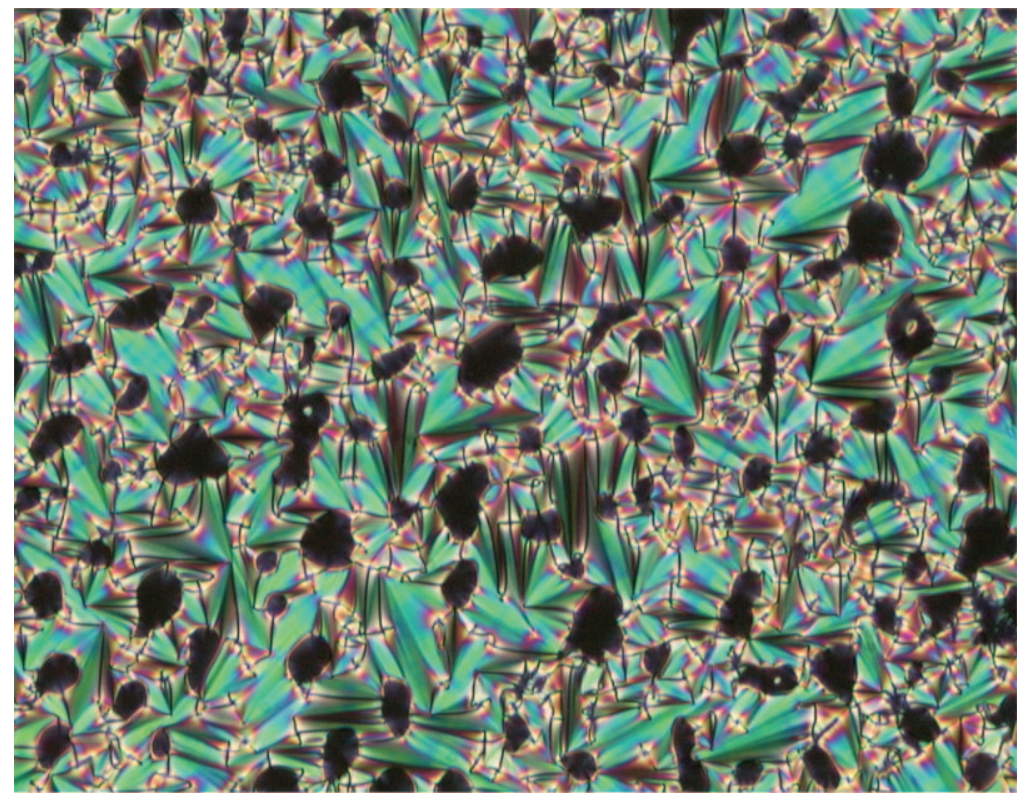

Fig. 2. Thermal-polarized optical micrograph of the focal-conic fan texture displayed by 4 in the smectic $A$ phase upon cooling the sample from the isotropic liquid to $199^{\circ}$ 


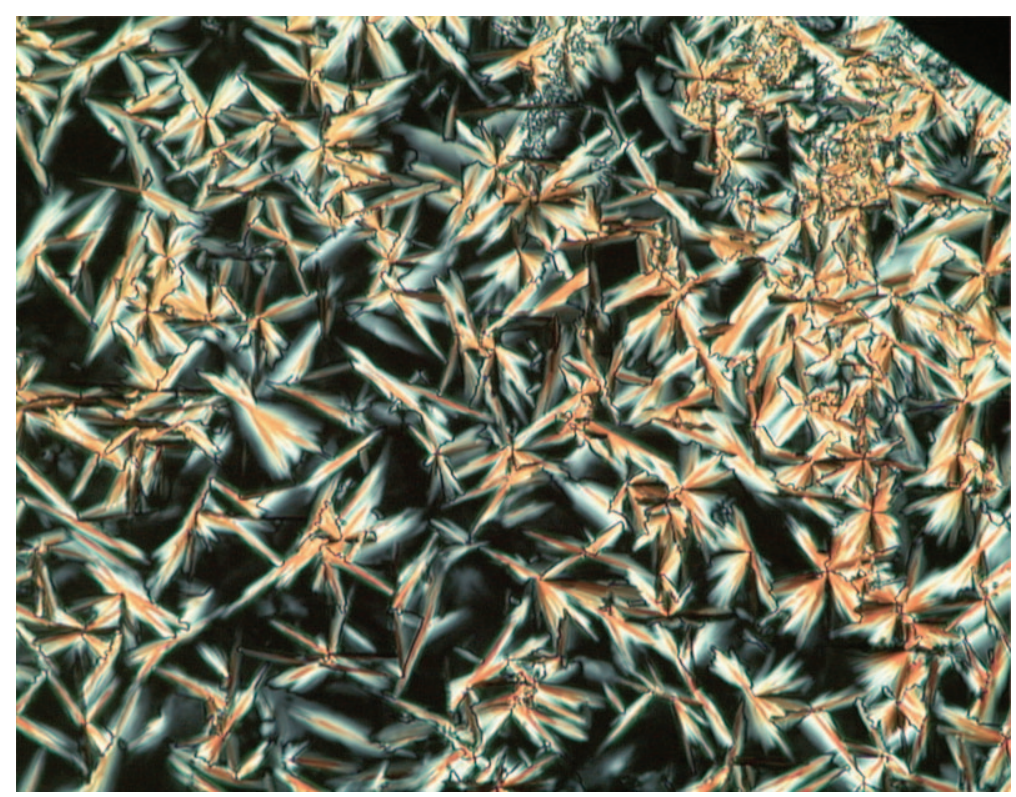

Fig. 3. Thermal-polarized optical micrograph of the pseudo-focal conic texture displayed by 7 in the columnar phase upon cooling the sample from the isotropic liquid to $82^{\circ}$

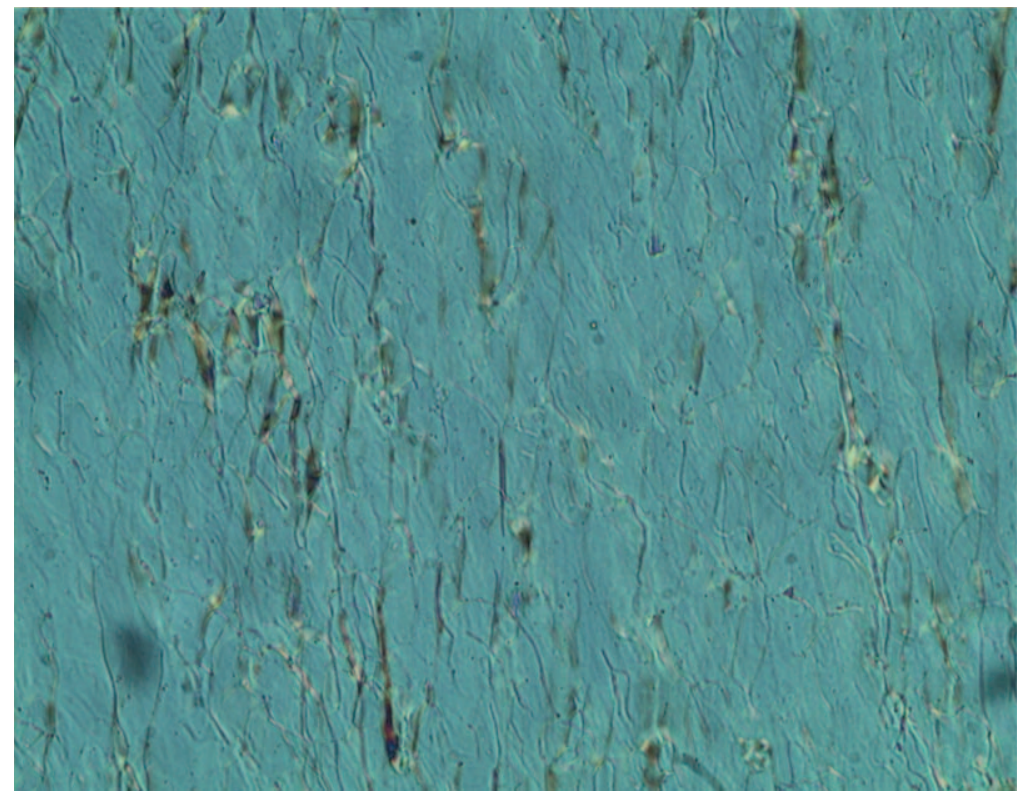

Fig. 4. Thermal-polarized optical micrograph of the texture displayed by $\mathbf{8}$ in the nematic chiral phase upon cooling the sample from the isotropic liquid to $99^{\circ}$ 
Scheme 6), and 2) the ligand-exchange reaction [17] $(\rightarrow \mathbf{I I}$; Scheme 7). From the point of view of functionalization, the direct method [8] leads to full coverage of the nanoparticles surface with the desired thiol derivative; on the other hand, the ligandexchange reaction [17] allows to control the loading of the desired thiol derivative on the gold surface. In this preliminary study, both reactions were carried out with ligand $\mathbf{1}$.

Scheme 6

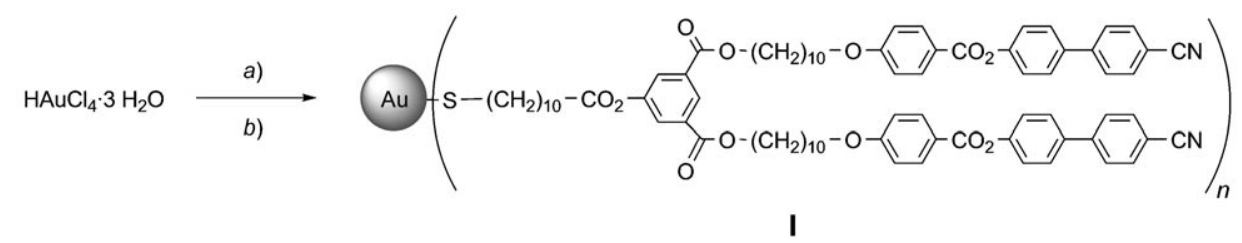

a) Tetraoctylammonium bromide (TOAB), toluene/ $\mathrm{H}_{2} \mathrm{O} 4: 1$, r.t., a few min. $b$ ) Compound $\mathbf{1}, 30 \mathrm{~min}$, then $\mathrm{NaBH}_{4}$, toluene, r.t., inert atmosphere, $24 \mathrm{~h} ; 3 \%$.

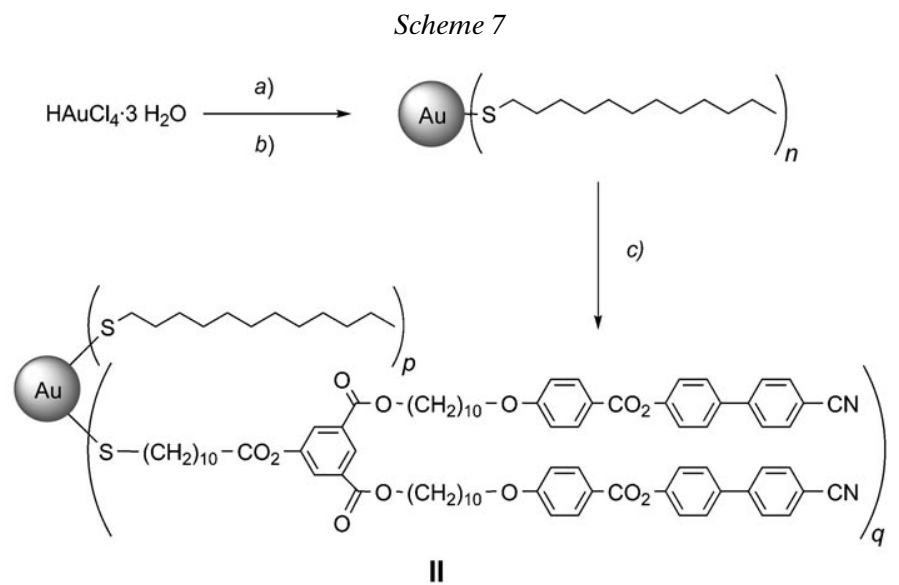

a) TOAB, toluene/ $\mathrm{H}_{2} \mathrm{O} 4: 1$, r.t., a few min. $b$ ) Dodecane-1-thiol, 30 min, then $\mathrm{NaBH}_{4}$, toluene, r.t., $1 \mathrm{~h}$, $30 \%$. c) Compound $1, \mathrm{CH}_{2} \mathrm{Cl}_{2}$, r.t., inert atmosphere, $72 \mathrm{~h} ; 50 \%$.

The direct synthesis led to nanoparticles I with an average diameter of $1.2 \pm$ $0.4 \mathrm{~nm}^{1}$ ) (Fig. 5). A few considerably larger particles (up to $7 \mathrm{~nm}$ ) were visible in the TEM image (Fig. 5). The ligand-exchange reaction (synthesis of gold nanoparticles with dodecane-1-thiol, followed by exchange of dodecane-1-thiol with 1) led to nanoparticles II with an average diameter of $1.7 \pm 0.4 \mathrm{~nm}^{2}$ ) (Fig. 6). The main advantages of the latter approach are: 1) the size of the gold nanoparticles can be controlled (first step), and 2) the ligands ratio can be adjusted (second step).

1) Size and size distribution were estimated from a sample of 1755 particles (minimum size: $0.74 \mathrm{~nm}$, maximum size: $6.98 \mathrm{~nm}$ ).

2) Size and size distribution were estimated from a sample of 2575 particles (minimum size: $0.70 \mathrm{~nm}$, maximum size: $5.31 \mathrm{~nm}$ ). 


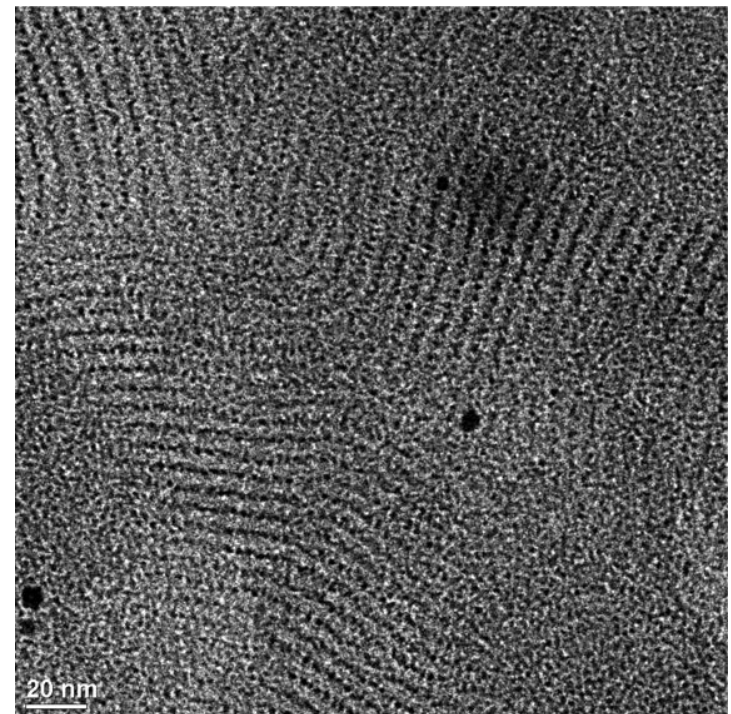

Fig. 5. TEM Micrograph showing rows of 1.2-nm gold nanoparticles $\mathbf{I}$

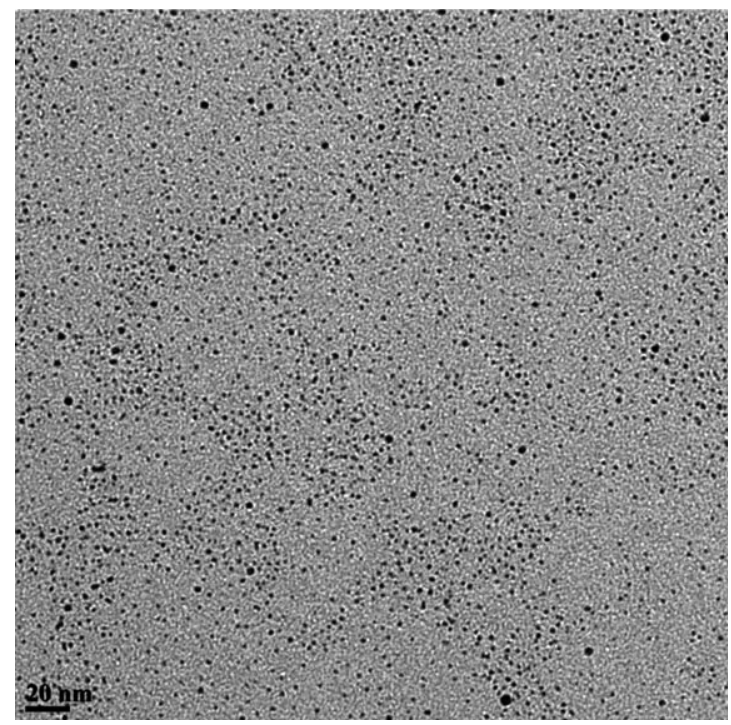

Fig. 6. TEM Micrograph showing 1.7-nm gold nanoparticles II

Different techniques were used to purify the nanoparticles, depending on the preparation method. For the direct synthesis, the nanoparticles were purified by sizeexclusion chromatography (see Exper. Part). For the exchange reaction, the nanoparticles covered with dodecane-1-thiol were purified by membrane filtration and the final materials by ultrafiltration (see Exper. Part). In addition, the particle core size was 
estimated to be lower than ca. $2 \mathrm{~nm}$ by UV/VIS spectroscopy (no plasmon band located at $c a .520 \mathrm{~nm}$ ) and further validated by TEM observations (Figs. 5 and 6).

The structure and purity of the gold nanoparticles were confirmed by ${ }^{1} \mathrm{H}-\mathrm{NMR}$ spectroscopy (Figs. 7 and 8): broadening of the peaks for the thiol derivatives grafted on the gold surface and disappearance of the $\mathrm{CH}_{2} \mathrm{SH}$ signal [8][18] evidenced that the ligands are grafted onto the gold surface. For II, the relative amount of ligand $\mathbf{1}$ with respect to dodecane-1-thiol was estimated from the spectrum of the mixed system (part D of Fig. 8), and was found to be $c a$. $40 \%$. Finally, the absence of sharp peaks indicated the absence of free thiol in the samples.

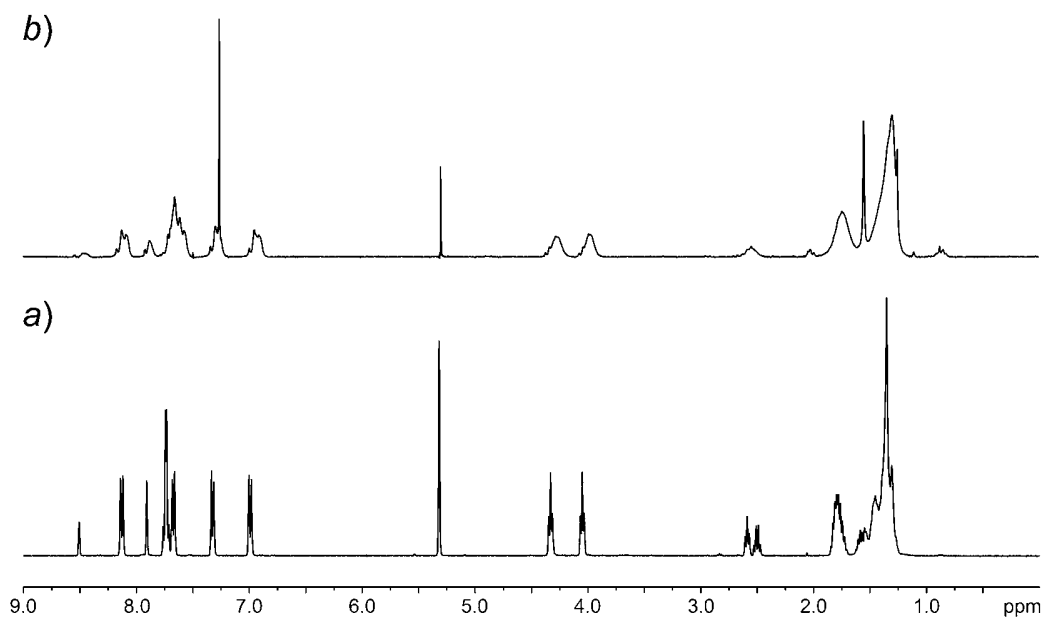

Fig. 7. ${ }^{1} \mathrm{H}$-NMR Spectra (in $\mathrm{CD}_{2} \mathrm{Cl}_{2}$ ) of compound $\mathbf{1}(a)$ and gold nanoparticles $\mathbf{I}(b)$

5. Self-Organization Behavior. Compound $\mathbf{1}$ attached to gold nanoparticles promoted an unexpected organization on carbon-coated copper grids: the particles arrange in evenly spaced rows (Fig. 5). In this organization, the particle cores within one row are closely packed, and separated from each other by less than $1 \mathrm{~nm}$. The separation between the rows is $c a .6 .5 \mathrm{~nm}$, which corresponds to 1.3 times the length of compound $\mathbf{1}(L=5.3 \mathrm{~nm})$ in its fully extended conformation. This can be interpreted as the formation of layers, as for smectic phases, with interdigitation of the cyanobiphenyl mesogenic units from one layer to the adjacent one. Interestingly, decreasing the dendrimer loading on the gold particle surface from 100 to $40 \%$ results in a less pronounced organization (not shown) or even in a complete loss of organization (Fig. 6). Thus, compound $\mathbf{1}$ acts as a self-organization promoter of gold particles, provided that sufficient loading is reached. Such organized structures may find applications in optical devices such as in optical waveguides or diffraction gratings due to the large local variation of the refractive index. Particularly interesting is the fact that, by this method, very short periodicities can be obtained.

Conclusions. - We have synthesized liquid-crystalline thiol- and disulfide-based ligands which display mesomorphism, in agreement with their structures. In this 


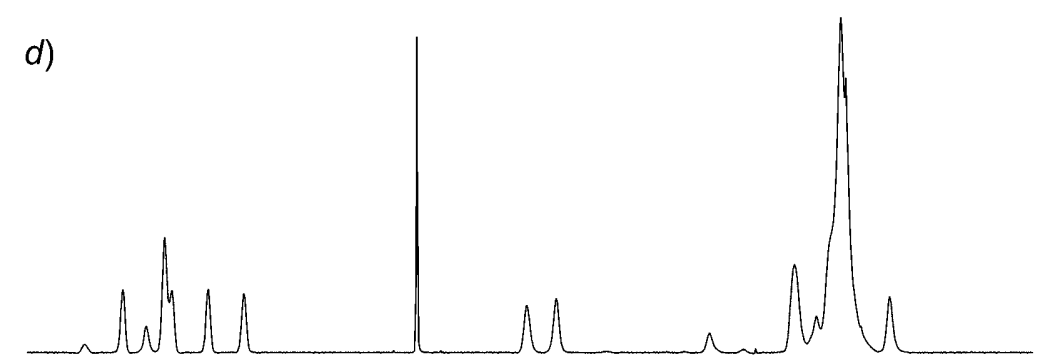

c)

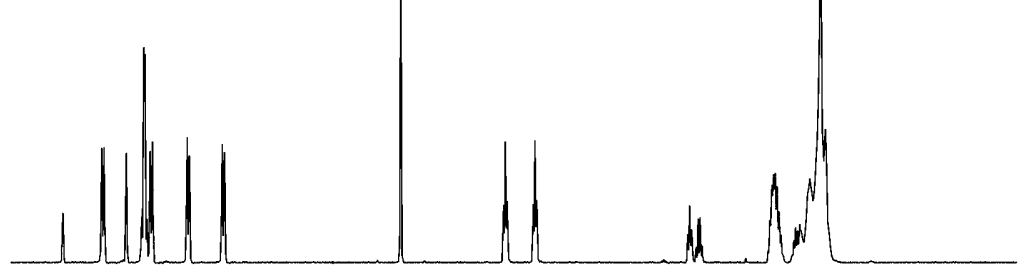

b)

)

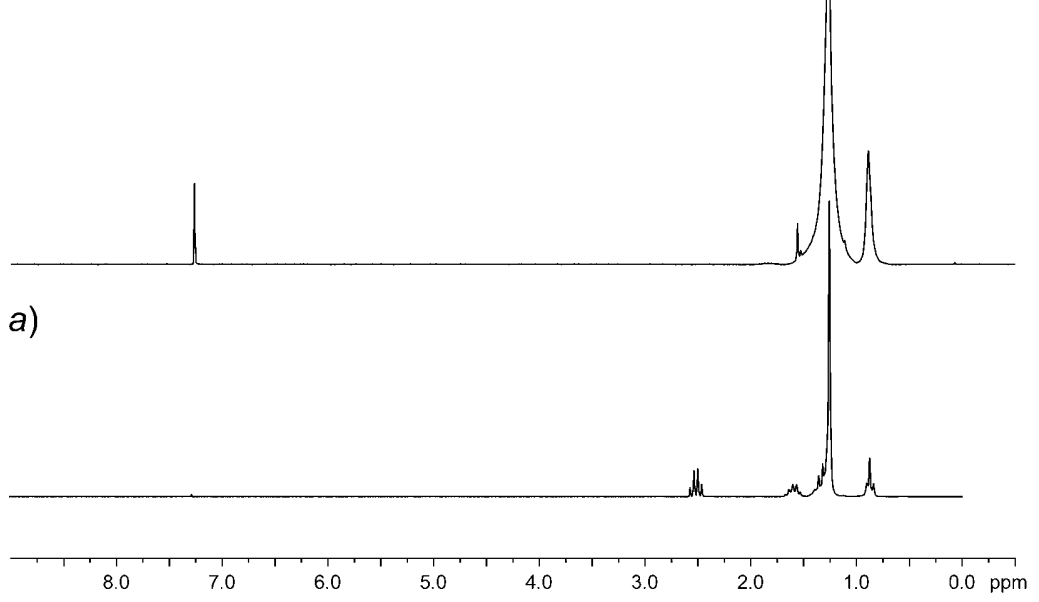

Fig. 8. ${ }^{1} \mathrm{H}$-NMR Spectra of dodecane-1-thiol $\left(a\right.$; in $\left.\mathrm{CDCl}_{3}\right)$, dodecane-1-thiol-stabilized gold nanoparticles ( $b$; in $\left.\mathrm{CDCl}_{3}\right)$, compound $\mathbf{1}\left(c\right.$; in $\left.\mathrm{CD}_{2} \mathrm{Cl}_{2}\right)$, and gold nanoparticles $\mathbf{I I}\left(d\right.$; in $\left.\mathrm{CD}_{2} \mathrm{Cl}_{2}\right)$

preliminary study, one of these ligands was used to stabilize and organize gold nanoparticles, the other ligands could also provide stabilization and organization of gold nanoparticles as well as of other metallic nanoparticles. The gold nanoparticles obtained in this study did not show mesomorphism. However, a surface organization on the nanometer scale was observed when spreading the materials onto a carbon-coated copper grid. Our results open up the design of organometallic materials with temperature-dependent optical properties by a bottom-up approach. 
The authors thank the Swiss National Science Foundation (Grants No. 200021-109176 and 200020117676) and the CICYT-FEDER Spanish project CTQ2006-15611-C02-01 for financial support.

\section{Experimental Part}

General. UV/VIS Spectra: Varian Cary 50 spectrophotometer; in $\mathrm{CH}_{2} \mathrm{Cl}_{2}$ before normalization. ${ }^{1} \mathrm{H}$-NMR Spectra: Bruker 400 spectrometer with the solvent as an internal reference (chemical shifts $\delta$ in ppm). Polarized optical microscopy (POM): Zeiss-Axioskop polarizing microscope equipped with a Linkam THMS-600 variable-temp. stage, under $\mathrm{N}_{2}$. Transition temp. and enthalpies were determined on a Mettler-Toledo $822 e$ differential-scanning calorimeter at a rate of $10 \%$ min under $\mathrm{He} / \mathrm{N}_{2}$. The XRD patterns were obtained with a pinhole camera (Anton-Paar) operating with a point-focussed Ni-filtered $\mathrm{Cu} / K_{\alpha}$ beam. The samples were held in Lindemann glass capillaries (1-mm diameter) and heated, when necessary, with a variable-temp. oven. The capillary was perpendicular to the X-ray beam, and the patterns were collected on a flat photographic film perpendicular to the beam. Spacings were obtained via Bragg's law. Transmission electron microscopy (TEM): Philips C200 electron microscope operating at $200 \mathrm{kV}$. The nanoparticles were dissolved in $\mathrm{CH}_{2} \mathrm{Cl}_{2}$, and the samples were prepared by drop-casting the soln. onto a 300-mesh carbon-coated copper grid. TEM Images were analyzed with the help of Image $J$, a free, public-domain program that is useful for the rapid counting of large numbers of particles [19]; further information is provided on the american $N I H$-dedicated website: http://rsb.info.nih.gov/ij.

Synthesis of 1. To a soln. of 9 [13] (4.85 g, $4.45 \mathrm{mmol})$ and 11-sulfanylundecanoic acid (486 $\mathrm{mg}$, $2.23 \mathrm{mmol})$ in dry $\mathrm{CH}_{2} \mathrm{Cl}_{2}(250 \mathrm{ml})$ at $0^{\circ}$ were added 4-(dimethylamino)pyridinium para-toluenesulfonate (DPTS) (655 mg, $2.23 \mathrm{mmol}), N, N^{\prime}$-dicyclohexylcarbodiimide (DCC) $(2.30 \mathrm{~g}, 11.13 \mathrm{mmol})$, and 4pyrrolidinopyridine (4-ppy; spatula tip). The mixture was stirred for $24 \mathrm{~h}$ at r.t., and the solvent was evaporated under vacuum. Purification of the crude material by column chromatography (CC; silica gel $\left.63-200 \mu \mathrm{m} ; \mathrm{CH}_{2} \mathrm{Cl}_{2}\right)$ and precipitation from $\mathrm{CH}_{2} \mathrm{Cl}_{2}$ with $\mathrm{MeOH}$ gave pure $\mathbf{1}(1.32 \mathrm{~g}, 46 \%)$.

Compounds $2-8$ were synthesized according to the above procedure, and were purified by CC (silica gel 63-200 $\mu \mathrm{m}$ ) with $\mathrm{CH}_{2} \mathrm{Cl}_{2}$ (for $\mathbf{2 , 3}, \mathbf{4 , 7}$, and $\mathbf{8}$ ) or $\mathrm{CH}_{2} \mathrm{Cl}_{2} /$ heptane (for 5 and $\mathbf{6}$ ) as eluent. The chemical yields are indicated in the Scheme captions.

Data of Bis[10-(4-\{[(4'-cyanobiphenyl-4-yl)oxy]carbonyl\}phenoxy)decyl] 5-[(11-Sulfanylundecanoyl)oxy]benzene-1,3-dicarboxylate $\left.(\mathbf{1})^{3}\right) .{ }^{1} \mathrm{H}-\mathrm{NMR}\left(400 \mathrm{MHz}, \mathrm{CD}_{2} \mathrm{Cl}_{2}\right): 8.49(t, 1$ arom. $\mathrm{H}) ; 8.11(d, 4$ arom. $\mathrm{H}) ; 7.89(d, 2$ arom. $\mathrm{H}) ; 7.73(d, 4$ arom. $\mathrm{H}) ; 7.71(d, 4$ arom. $\mathrm{H}) ; 7.65(d, 4$ arom. $\mathrm{H}) ; 7.31$ ( $d, 4$ arom. $\mathrm{H}) ; 6.97(d, 4$ arom. $\mathrm{H}) ; 4.31\left(t, 2 \mathrm{CO}_{2} \mathrm{CH}_{2}\right) ; 4.03\left(t, 2 \mathrm{CH}_{2} \mathrm{O}\right) ; 2.57\left(t, \mathrm{CH}_{2} \mathrm{CO}_{2}\right) ; 2.48\left(q, \mathrm{CH}_{2} \mathrm{SH}\right) ; 1.83-$ $1.69\left(m, 2 \mathrm{CO}_{2} \mathrm{CH}_{2} \mathrm{CH}_{2}, 2 \mathrm{CH}_{2} \mathrm{CH}_{2} \mathrm{O}, \mathrm{CH}_{2} \mathrm{CH}_{2} \mathrm{CO}_{2}, \mathrm{CH}_{2} \mathrm{CH}_{2} \mathrm{SH}\right) ; 1.37-1.26(m, 36$ aliph. H). Anal. calc. for $\mathrm{C}_{79} \mathrm{H}_{88} \mathrm{~N}_{2} \mathrm{O}_{12} \mathrm{~S}$ (1289.62): C 73.58, H 6.88, N 2.17, S 2.49; found: C 73.48, H 6.68, N 2.31, S 2.33.

Data of Bis[10-(4-\{[(4'-cyanobiphenyl-4-yl)oxy]carbonyl\}phenoxy)decyl] 5-\{[5-(1,2-Dithiolan-3-yl)pentanoylloxy]benzene-1,3-dicarboxylate $\left.(2)^{3}\right) .{ }^{1} \mathrm{H}-\mathrm{NMR}\left(400 \mathrm{MHz}, \mathrm{CD}_{2} \mathrm{Cl}_{2}\right): 8.50(t, 1$ arom. $\mathrm{H}) ; 8.11$ $(d, 4$ arom. $\mathrm{H}) ; 7.91(d, 2$ arom. $\mathrm{H}) ; 7.73(d, 4$ arom. $\mathrm{H}) ; 7.71(d, 4$ arom. $\mathrm{H}) ; 7.65(d, 4$ arom. $\mathrm{H}) ; 7.31(d, 4$ arom. $\mathrm{H}) ; 6.98(d, 4$ arom. $\mathrm{H}) ; 4.32\left(t, 2 \mathrm{CO}_{2} \mathrm{CH}_{2}\right) ; 4.03\left(t, 2 \mathrm{CH}_{2} \mathrm{O}\right) ; 3.62-3.55(m, \mathrm{CH}) ; 3.20-3.07(m$, $\left.\mathrm{SCH}_{2}\right) ; 2.61\left(t, \mathrm{CH}_{2} \mathrm{CO}_{2}\right) ; 2.49-2.41\left(m, \mathrm{SCH}_{2} \mathrm{CH}_{\mathrm{a}}\right) ; 1.95-1.88\left(m, \mathrm{SCH}_{2} \mathrm{CH}_{\mathrm{b}}\right) ; 1.82-1.68(m$, $\left.2 \mathrm{CO}_{2} \mathrm{CH}_{2} \mathrm{CH}_{2}, \mathrm{CH}_{2} \mathrm{CH}_{2} \mathrm{CO}_{2}, 2 \mathrm{CH}_{2} \mathrm{CH}_{2} \mathrm{O}, \mathrm{CHCH}_{2}\right) ; 1.46-1.30$ ( $m, 26$ aliph. H). Anal. calc. for $\mathrm{C}_{76} \mathrm{H}_{80} \mathrm{~N}_{2} \mathrm{O}_{12} \mathrm{~S}_{2}$ (1277.59): C 71.45, H 6.31, N 2.19, S 5.02; found: C 71.27, H 6.40, N 2.24, S 5.03.

Data of 3. ${ }^{1} \mathrm{H}-\mathrm{NMR}\left(400 \mathrm{MHz}, \mathrm{CD}_{2} \mathrm{Cl}_{2}\right): 8.89(t, 1$ arom. $\mathrm{H}) ; 8.59(t, 2$ arom. $\mathrm{H}) ; 8.22(d, 2$ arom. $\mathrm{H})$; $8.12(d, 8$ arom. $\mathrm{H}) ; 8.10(d, 4$ arom. $\mathrm{H}) ; 7.74(d, 8$ arom. $\mathrm{H}) ; 7.72(d, 8$ arom. $\mathrm{H}) ; 7.67(d, 8$ arom. $\mathrm{H}) ; 7.32$ $(d, 8$ arom. $\mathrm{H}) ; 6.98(d, 8$ arom. $\mathrm{H}) ; 4.35\left(t, 4 \mathrm{CO}_{2} \mathrm{CH}_{2}\right) ; 4.04\left(t, 4 \mathrm{CH}_{2} \mathrm{O}\right) ; 2.64\left(t, \mathrm{CH}_{2} \mathrm{CO}_{2}\right) ; 2.49(q$, $\left.\mathrm{CH}_{2} \mathrm{SH}\right)$; $1.84-1.75\left(m, 4 \mathrm{CO}_{2} \mathrm{CH}_{2} \mathrm{CH}_{2}, 4 \mathrm{CH}_{2} \mathrm{CH}_{2} \mathrm{O}, \mathrm{CH}_{2} \mathrm{CH}_{2} \mathrm{CO}_{2}, \mathrm{CH}_{2} \mathrm{CH}_{2} \mathrm{SH}\right) ; 1.47-1.30$ (m, 60 aliph. H). Anal. calc. for $\mathrm{C}_{155} \mathrm{H}_{158} \mathrm{~N}_{4} \mathrm{O}_{26} \mathrm{~S}$ (2525.04): C 73.73, H 6.31, N 2.22, S 1.27; found: C 73.35, H 6.35, N 2.17, S 1.43.

Data of 4. ${ }^{1} \mathrm{H}-\mathrm{NMR}\left(400 \mathrm{MHz}, \mathrm{CD}_{2} \mathrm{Cl}_{2}\right): 8.89(t, 1$ arom. $\mathrm{H}) ; 8.59(t, 2$ arom. $\mathrm{H}) ; 8.23(d, 2$ arom. $\mathrm{H})$; $8.12(d, 8$ arom. $\mathrm{H}) ; 8.10(d, 4$ arom. $\mathrm{H}) ; 7.74(d, 8$ arom. $\mathrm{H}) ; 7.72(d, 8$ arom. $\mathrm{H}) ; 7.67(d, 8$ arom. $\mathrm{H}) ; 7.32$

3) As representative nomenclature examples, the systematic names of compounds $\mathbf{1}, \mathbf{2}, \mathbf{5}$, and $\mathbf{6}$ are provided. 
$(d, 8$ arom. $\mathrm{H}) ; 6.98(d, 8$ arom. $\mathrm{H}) ; 4.35\left(t, 4 \mathrm{CO}_{2} \mathrm{CH}_{2}\right) ; 4.04\left(t, 4 \mathrm{CH}_{2} \mathrm{O}\right) ; 3.64-3.57(m, \mathrm{CH}) ; 3.20-3.08$ $\left(m, \mathrm{SCH}_{2}\right) ; 2.67\left(t, \mathrm{CH}_{2} \mathrm{CO}_{2}\right) ; 2.50-2.42\left(m, \mathrm{SCH}_{2} \mathrm{CH}_{\mathrm{a}}\right) ; 1.96-1.87\left(m, \mathrm{SCH}_{2} \mathrm{CH}_{\mathrm{b}}\right) ; 1.82-1.76(m$, $\left.4 \mathrm{CO}_{2} \mathrm{CH}_{2} \mathrm{CH}_{2}, 4 \mathrm{CH}_{2} \mathrm{CH}_{2} \mathrm{O}, \mathrm{CHCH}_{2}\right) ; 1.47-1.35$ ( $m, 52$ aliph. H). Anal. calc. for $\mathrm{C}_{152} \mathrm{H}_{150} \mathrm{~N}_{4} \mathrm{O}_{26} \mathrm{~S}_{2}$ (2512.96): C 72.65, H 6.02, N 2.23, S 2.55; found: C 72.37, H 6.07, N 2.21, S 2.60.

Data of 3,5-Bis[(3,4,5-tris\{[4-(dodecyloxy)benzyl]oxy\}benzyl)oxy]benzyl 11-sulfanylundecanoate $\left.(5)^{3}\right) .{ }^{1} \mathrm{H}$-NMR $\left(400 \mathrm{MHz}, \mathrm{CD}_{2} \mathrm{Cl}_{2}\right): 7.31(d, 8$ arom. $\mathrm{H}) ; 7.29(d, 4$ arom. $\mathrm{H}) ; 6.88(d, 8$ arom. $\mathrm{H}) ; 6.78$ $6.73(m, 8$ arom. $\mathrm{H}) ; 6.60(d, 2$ arom. $\mathrm{H}) ; 6.56(t, 1$ arom. $\mathrm{H}) ; 5.06-5.02\left(m, \mathrm{CO}_{2} \mathrm{CH}_{2} \mathrm{Ar}, 4 \mathrm{OCH}_{2} \mathrm{Ar}\right) ; 4.93$ $\left(m, 4 \mathrm{OCH}_{2} \mathrm{Ar}\right) ; 3.97-3.86\left(m, 6 \mathrm{OCH}_{2}\right) ; 2.49\left(t, \mathrm{CH}_{2} \mathrm{CO}_{2}\right) ; 2.32\left(q, \mathrm{CH}_{2} \mathrm{SH}\right) ; 1.81-1.72(m$, $\left.6 \mathrm{OCH}_{2} \mathrm{CH}_{2}, \mathrm{CH}_{2} \mathrm{CH}_{2} \mathrm{CO}_{2}\right) ; 1.44-1.27$ ( $m, 122$ aliph. $\left.\mathrm{H}\right)$; $0.89(t, 6 \mathrm{Me})$. Anal. calc. for $\mathrm{C}_{146} \mathrm{H}_{220} \mathrm{O}_{16} \mathrm{~S}$ (2263.36): C 77.48, H 9.80, S 1.42; found: C 77.18, H 9.84, S 1.56.

Data of 3,5-Bis[(3,4,5-tris\{[4-(dodecyloxy)benzyl]oxy\}benzyl)oxy]benzyl 5-(1,2-dithiolan-3-yl)pentanoate $\left.(6)^{3}\right) .{ }^{1} \mathrm{H}-\mathrm{NMR}\left(400 \mathrm{MHz}, \mathrm{CDCl}_{3}\right): 7.31(d, 8$ arom. $\mathrm{H}) ; 7.27(d, 4$ arom. $\mathrm{H}) ; 6.87(d, 8$ arom. $\mathrm{H})$; $6.76(d, 4$ arom. $\mathrm{H}) ; 6.73(s, 4$ arom. $\mathrm{H}) ; 6.59(d, 2$ arom. $\mathrm{H}) ; 6.56(t, 1$ arom. $\mathrm{H}) ; 5.06\left(s, \mathrm{CO}_{2} \mathrm{CH}_{2} \mathrm{Ar}\right) ; 5.02$ $\left(s, 4 \mathrm{OCH}_{2} \mathrm{Ar}\right) ; 4.92\left(s, 2 \mathrm{OCH}_{2} \mathrm{Ar}\right) ; 4.91\left(s, 2 \mathrm{OCH}_{2} \mathrm{Ar}\right) ; 3.97-3.90\left(m, 6 \mathrm{OCH}_{2} \mathrm{CH}_{2}\right) ; 3.53-3.48(m$, $\mathrm{CH}) ; 3.15-3.03\left(m, \mathrm{SCH}_{2}\right) ; 2.42-2.30\left(m, \mathrm{CH}_{2} \mathrm{CO}_{2}, \mathrm{SCH}_{2} \mathrm{CH}_{\mathrm{a}}\right) ; 1.81-1.72\left(m, 6 \mathrm{OCH}_{2} \mathrm{CH}_{2}\right.$, $\mathrm{CH}_{2} \mathrm{CH}_{2} \mathrm{CO}_{2}, \mathrm{CHCH}_{2}, \mathrm{SCH}_{2} \mathrm{CH}_{\mathrm{b}}$ ); $1.44-1.27$ ( $m, 110$ aliph. $\left.\mathrm{H}\right) ; 0.88$ ( $\left.t, 6 \mathrm{Me}\right)$. Anal. calc. for $\mathrm{C}_{143} \mathrm{H}_{212} \mathrm{O}_{16} \mathrm{~S}_{2}$ (2251.37): C 76.29, H 9.49, S 2.85; found: C 76.26, H 9.34, S 2.74.

Data of 7. ${ }^{1} \mathrm{H}-\mathrm{NMR}\left(400 \mathrm{MHz}, \mathrm{CD}_{2} \mathrm{Cl}_{2}\right)$ : $7.31(d, 16$ arom. $\mathrm{H}) ; 7.22(d, 8$ arom. $\mathrm{H}) ; 6.87(d, 16$ arom. $\mathrm{H}) ; 6.75(s, 8$ arom. $\mathrm{H}) ; 6.72(d, 8$ arom. $\mathrm{H}) ; 6.69(d, 4$ arom. $\mathrm{H}) ; 6.61-6.58(m, 3$ arom. $\mathrm{H}) ; 6.56(t, 2$ arom. $\mathrm{H}) ; 5.03\left(s, \mathrm{CO}_{2} \mathrm{CH}_{2} \mathrm{Ar}\right) ; 5.00\left(s, 2 \mathrm{OCH}_{2} \mathrm{Ar}\right) ; 4.98\left(s, 8 \mathrm{OCH}_{2} \mathrm{Ar}\right) ; 4.94\left(s, 4 \mathrm{OCH}_{2} \mathrm{Ar}\right) ; 4.87(s$, $\left.4 \mathrm{OCH}_{2} \mathrm{Ar}\right) ; 3.94-3.89\left(m, 12 \mathrm{OCH}_{2} \mathrm{CH}_{2}\right) ; 3.52-3.48(\mathrm{~m}, \mathrm{CH}) ; 3.09-3.01\left(m, \mathrm{SCH}_{2}\right) ; 2.37-2.32(m$, $\left.\mathrm{SCH}_{2} \mathrm{CH}_{\mathrm{a}}, \mathrm{CH}_{2} \mathrm{CO}_{2}\right) ; 1.83-1.81\left(m, \mathrm{SCH}_{2} \mathrm{CH}_{\mathrm{b}}\right) ; 1.77-1.73\left(m, 12 \mathrm{OCH}_{2} \mathrm{CH}_{2}\right) ; 1.65-1.60\left(m, \mathrm{CHCH}_{2}\right.$, $\left.\mathrm{CH}_{2} \mathrm{CH}_{2} \mathrm{CO}_{2}\right) ; 1.44-1.27(m, 218$ aliph. $\mathrm{H}) ; 0.87(t, 12 \mathrm{Me})$. Anal. calc. for $\mathrm{C}_{285} \mathrm{H}_{416} \mathrm{O}_{32} \mathrm{~S}_{2}$ (4418.53): $\mathrm{C}$ 77.47, H 9.49, S 1.45; found: C 77.47, H 9.50, S 1.38 .

Data of 8. ${ }^{1} \mathrm{H}-\mathrm{NMR}\left(400 \mathrm{MHz}, \mathrm{CD}_{2} \mathrm{Cl}_{2}\right): 8.48(t, 1$ arom. $\mathrm{H}) ; 8.25(d, 4$ arom. $\mathrm{H}) ; 8.00(d, 2$ arom. $\mathrm{H})$; $7.88(d, 2$ arom. $\mathrm{H}) ; 7.61(d, 4$ arom. $\mathrm{H}) ; 7.54(d, 4$ arom. $\mathrm{H}) ; 7.35(d, 4$ arom. $\mathrm{H}) ; 7.25(d, 4$ arom. $\mathrm{H}) ; 6.97$ $(d, 4$ arom. $\mathrm{H}) ; 6.57-6.53(m, 4$ arom. $\mathrm{H}) ; 4.28\left(t, 2 \mathrm{CO}_{2} \mathrm{CH}_{2}\right) ; 4.06,4.00\left(2 t, 4 \mathrm{OCH}_{2} \mathrm{CH}_{2}\right) ; 3.92-3.80(m$, $\left.2 \mathrm{CHCH}_{2} \mathrm{O}\right) ; 3.61-3.54(m, \mathrm{CH}) ; 3.20-3.06\left(m, \mathrm{SCH}_{2}\right) ; 2.57\left(t, \mathrm{CH}_{2} \mathrm{CO}_{2}\right) ; 2.48-2.40\left(m, \mathrm{SCH}_{2} \mathrm{CH}_{\mathrm{a}}\right)$; 1.90-1.69 (m, $\left.2 \mathrm{CO}_{2} \mathrm{CH}_{2} \mathrm{CH}_{2}, \mathrm{CH}_{2} \mathrm{CH}_{2} \mathrm{CO}_{2}, 4 \mathrm{CH}_{2} \mathrm{CH}_{2} \mathrm{O}, 2 \mathrm{CH}, \mathrm{SCHCH}_{2}, \mathrm{SCH}_{2} \mathrm{CH}_{\mathrm{b}}\right) ; 1.60-1.46(m$, $2 \mathrm{MeCH}_{2} \mathrm{CH}, 30$ aliph. H); $1.03(d, 2 \mathrm{MeCH}) ; 0.96\left(t, 2 \mathrm{MeCH} \mathrm{CH}_{2}\right) ; 0.90\left(t, 2 \mathrm{MeCH}_{2} \mathrm{CH}_{2}\right)$. Anal. calc. for $\mathrm{C}_{106} \mathrm{H}_{126} \mathrm{O}_{20} \mathrm{~S}_{2}$ (1784.25): C 71.35, H 7.12, S 3.59; found: C 71.09, H 7.14, S 3.41.

General Procedure for the Synthesis of the Gold Nanoparticles. Chemicals were purchased from Sigma-Aldrich and $\mathrm{NaBH}_{4}$ from Acros Organics.

Synthesis of $\mathbf{I}$. According to the two-phase method [8] with a ratio of 1, 3.5, 3, and 20 equiv. for $\mathrm{HAuCl}_{4} \cdot 3 \mathrm{H}_{2} \mathrm{O}$, tetraoctylammonium bromide (TOAB), 1 , and $\mathrm{NaBH}_{4}$, resp. Purification of the particles was performed with Bio-Rad Bio-Beads $S$-X1 (1\% cross-linked; separated molecular weights: $600-14000 \mathrm{Da})$.

Synthesis of $\mathbf{I I}$. To a moderately stirred $\mathrm{CH}_{2} \mathrm{Cl}_{2}(5 \mathrm{ml})$ soln. containing dodecane-1-thiol-stabilized gold nanoparticles [8] (50 mg, $3.8 \mu \mathrm{mol}$, purified over Sartorius-regenerated cellulose membranes with a $0.2-\mu \mathrm{m}$ pore size $)$ was added a soln. of $\mathbf{1}(240 \mathrm{mg}, 0.19 \mathrm{mmol})$ in $\mathrm{CH}_{2} \mathrm{Cl}_{2}(5 \mathrm{ml})$. The mixture was stirred under inert atmosphere at r.t. for $72 \mathrm{~h}$, and filtered (Millipore solvent-resistant ultrafiltration device with $30-\mathrm{kDa}$ regenerated cellulose ultrafiltration membrane under a 2.2 bar $\mathrm{N}_{2}$ pressure). The soln. containing II was evaporated to dryness.

Data of I. ${ }^{1} \mathrm{H}-\mathrm{NMR}\left(400 \mathrm{MHz}, \mathrm{CD}_{2} \mathrm{Cl}_{2}\right.$ ): 8.46 (br. $s, 1$ arom. H); 8.12 (br. $s, 4$ arom. H); 7.87 (br. $s, 2$ arom. H); 7.66 (br. $s, 12$ arom. H); 7.30 (br. $s, 4$ arom. H); 6.95 (br. $s, 4$ arom. H); 4.28 (br. $s, 2 \mathrm{CO}_{2} \mathrm{CH}_{2}$ ); 3.99 (br. $s, 2 \mathrm{CH}_{2} \mathrm{O}$ ); 2.55 (br. $s, \mathrm{CH}_{2} \mathrm{CO}_{2}$ ); 1.74 (br. $s, 10$ aliph. H); 1.30 (br. $s, 38$ aliph. H).

Data of II. ${ }^{1} \mathrm{H}-\mathrm{NMR}\left(400 \mathrm{MHz}, \mathrm{CD}_{2} \mathrm{Cl}_{2}\right.$; integration with respect to the signals of ligand $\mathbf{1}$ ): 8.46 (br. $s, 1$ arom. H); 8.10 (br. $s, 4$ arom. H); 7.87 (br. $s, 2$ arom. H); 7.70 and 7.63 (2 br. $s, 12$ arom. H); 7.29 (br. $s, 4$ arom. H); 6.96 (br. $s, 4$ arom. H); 4.28 (br. $s, 2 \mathrm{CO}_{2} \mathrm{CH}_{2}$ ); 4.00 (br. s, $2 \mathrm{CH}_{2} \mathrm{O}$ ); 2.55 (br. $s, \mathrm{CH}_{2} \mathrm{CO}_{2}$ ); 1.75 (br. $s, 10$ aliph. H); $1.65-0.97$ (72 aliph. H); 0.85 (br. $s, 5$ aliph. H). 


\section{REFERENCES}

[1] M.-C. Daniel, D. Astruc, Chem. Rev. 2004, 104, 293; H. Qi, T. Hegmann, J. Mater. Chem. 2008, 18, 3288 .

[2] N. Kanayama, O. Tsutsumi, A. Kanazawa, T. Ikeda, Chem. Commun. 2001, 2640.

[3] I. In, Y.-W. Jun, Y. J. Kim, S. Y. Kim, Chem. Commun. 2005, 800.

[4] L. Cseh, G. H. Mehl, J. Am. Chem. Soc. 2006, 128, 13376; L. Cseh, G. H. Mehl, J. Mater. Chem. 2007, $17,311$.

[5] B. Donnio, P. García-Vázquez, J.-L. Gallani, D. Guillon, E. Terazzi, Adv. Mater. 2007, 19, 3534.

[6] C. Rockstuhl, T. Scharf, J. Microsc. 2008, 229, 281.

[7] C. Rockstuhl, F. Lederer, C. Etrich, T. Pertsch, T. Scharf, Phys. Rev. Lett. 2007, 99, 017401.

[8] M. Brust, M. Walker, D. Bethell, D. J. Schiffrin, R. Whyman, J. Chem. Soc., Chem. Commun. 1994, 801; M. J. Hostetler, J. E. Wingate, C.-J. Zhong, J. E. Harris, R. W. Vachet, M. R. Clark, J. D. Londono, S. J. Green, J. J. Stokes, G. D. Wignall, G. L. Glish, M. D. Porter, N. D. Evans, R. W. Murray, Langmuir 1998, 14, 17.

[9] R. Deschenaux, B. Donnio, D. Guillon, New J. Chem. 2007, 31, 1064.

[10] S. Campidelli, E. Vázquez, D. Milic, M. Prato, J. Barberá, D. M. Guldi, M. Marcaccio, D. Paolucci, F. Paolucci, R. Deschenaux, J. Mater. Chem. 2004, 14, 1266; S. Campidelli, M. Séverac, D. Scanu, R. Deschenaux, E. Vázquez, D. Milic, M. Prato, M. Carano, M. Marcaccio, F. Paolucci, G. M. Aminur Rahman, D. M. Guldi, J. Mater. Chem. 2008, 18, 1504.

[11] S. Frein, M. Auzias, A. Sondenecker, L. Vieille-Petit, B. Guintchin, N. Maringa, G. Süss-Fink, J. Barberá, R. Deschenaux, Chem. Mater. 2008, 20, 1340.

[12] B. Donnio, D. Guillon, Adv. Polym. Sci. 2006, 201, 45; B. Donnio, S. Buathong, I. Bury, D. Guillon, Chem. Soc. Rev. 2007, 36, 1495; J. W. Goodby, I. M. Saez, S. J. Cowling, V. Görtz, M. Draper, A. W. Hall, S. Sia, G. Cosquer, S.-E. Lee, E. P. Raynes, Angew. Chem., Int. Ed. 2008, 47, 2754; I. M. Saez, J. W. Goodby, Struct. Bonding (Berlin) 2008, 128, 1.

[13] B. Dardel, D. Guillon, B. Heinrich, R. Deschenaux, J. Mater. Chem. 2001, 11, 2814.

[14] S. Campidelli, C. Eng, I. M. Saez, J. W. Goodby, R. Deschenaux, Chem. Commun. 2003, 1520.

[15] a) V. Percec, W.-D. Cho, G. Ungar, D. J. P. Yeardley, J. Am. Chem. Soc. 2001, 123, 1302; b) V. Percec, M. Glodde, T. K. Bera, Y. Miura, I. Shiyanovskaya, K. D. Singer, V. S. K. Balagurusamy, P. A. Heiney, I. Schnell, A. Rapp, H.-W. Spiess, S. D. Hudson, H. Duan, Nature 2002, 419, 384; c) G. Ungar, Y. Liu, X. Zeng, V. Percec, W.-D. Cho, Science 2003, 299, 1208; d) V. Percec, M. R. Imam, T. K. Bera, V. S. K. Balagurusamy, M. Peterca, P. A. Heiney, Angew. Chem., Int. Ed. 2005, 44, 4739; e) V. Percec A. E. Dulcey, M. Peterca, M. Ilies, M. J. Sienkowska, P. A. Heiney, J. Am. Chem. Soc. 2005, 127, 17902.

[16] R. A. Lewthwaite, J. W. Goodby, K. J. Toyne, J. Mater. Chem. 1993, 3, 241; I. M. Saez, J. W. Goodby, J. Mater. Chem. 2005, 15, 26.

[17] A. Kassam, G. Bremner, B. Clark, G. Ulibarri, R. B. Lennox, J. Am. Chem. Soc. 2006, 128, 3476; M. Hasan, D. Bethell, M. Brust, J. Am. Chem. Soc. 2002, 124, 1132.

[18] M. J. Hostetler, A. C. Templeton, R. W. Murray, Langmuir 1999, 15, 3782.

[19] G. H. Woehrle, J. E. Hutchison, S. Özkar, R. G. Finke, Turk. J. Chem. 2006, 30, 1. 